Ilija Bobić ${ }^{\text {, Bore Jegdić }}{ }^{2}$, Biljana Bobić ${ }^{2 *}$

${ }^{1}$ University of Belgrade, "Vinča" Institute of Nuclear Sciences, Belgrade, Serbia

${ }^{2}$ University of Belgrade, Institute of Chemistry, Technology and Metallurgy, Belgrade, Serbia
Scientific paper

ISSN 0351-9465, E-ISSN 2466-2585

UDC:620.197.7

doi:10.5937/zasmat1901018B

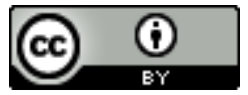

Zastita Materijala 60 (1)

$18-25$ (2019)

\title{
The resistance to general corrosion of series of zinc-aluminum alloys modified with silicon and strontium
}

\begin{abstract}
The resistance to corrosion of the series of zinc-aluminum casting alloys modified with silicon and strontium was studied in a sodium chloride solution. It was shown that general corrosion was the main form of corrosion of Zn25Al-Si-Sr alloys in the test solution. The corrosion process takes place through the anodic dissolution of the alloys, while the cathodic reaction is controlled by diffusion of oxygen in the test solution. Three different electrochemical techniques were applied to determine the corrosion current density, which is the electrochemical indicator of corrosion rate. The value of corrosion current density for each Zn25Al-Si-Sr alloy was calculated using the value of polarization resistance, obtained by electrochemical impedance spectroscopy or by linear polarization resistance technique. The value of corrosion current density was also determined directly from Tafel plots, which were recorded by linear sweep voltammetry. As the content of silicon and strontium in the tested alloys increases, the value of corrosion current density increases gradually. The results obtained by different electrochemical techniques are in good agreement.
\end{abstract}

Keywords: zinc-aluminum alloys, corrosion rate, electrochemical techniques.

\section{INTRODUCTION}

ZA27 alloy belongs to the family of zincaluminum (ZA) casting alloys with high aluminum content. It has been widely used in the production of sliding bearings because of high strength and hardness and favorable tribological characteristics. The alloy usually contains 25 to $28 \mathrm{wt} . \%$ aluminum, 2 to 2.5 wt.\% copper, and 0.01 to 0.02 wt.\% magnesium. The presence of copper has a beneficial effect on the hardness and tensile strength of the alloy. However, during long-term aging at ambient or slightly elevated temperatures copper can lead to irreversible changes in the dimensions of the alloy castings [1]. This unfavorable feature of commercial ZA27 alloy can be overcome by replacing the copper in the alloy with silicon $[2,3]$. Silicon also shows a beneficial effect on the wear resistance of zinc-aluminum alloys [4-6]. The wear resistance of alloys with silicon was found to be approximately five times

\footnotetext{
${ }^{\star}$ Corresponding author: Biljana Bobić

E-mail: biljanabobic@gmail.com

Paper received: 04. 07. 2018.

Paper corrected: 22. 08. 2018.

Paper accepted: 25. 08. 2018.

Paper is available on the website: www.idk.org.rs/journal
}

higher than the wear resistance of ZA27 alloy [7]. Adding of strontium to Zn25Al-Si alloys resulted in further improvement of their wear resistance [7]. Thus, Zn25Al-Si-Sr alloys can be regarded as respectable tribological materials intended for use in complex tribo-mechanical systems. For a successful application of these alloys in real conditions of exploitation (atmosphere, natural waters) it is also necessary to take their corrosion resistance in the relevant corrosive environment into account.

Corrosion behavior of zinc-aluminum casting alloys is similar to that of pure zinc. General corrosion is the main form of zinc corrosion under atmospheric conditions, in natural waters, aqueous solutions and soil. General corrosion occurs as a more or less uniform dissolution of the metal/alloy surface, which results with a gradual decrease in the metal/alloy thickness. Due to the presence of aluminum, zinc-aluminum casting alloys have better resistance to general corrosion than zinc [8, 9]. The resistance to corrosion depends on the alloy composition and structure, as well as on the chemical composition, concentration, $\mathrm{pH}$ and temperature of the corrosive environment, i.e. on the corrosivity of atmospheres. Atmospheres are usually classified as industrial, urban, rural or 
marine. The presence of chlorides from the sea is characteristic for marine atmosphere [8, 9].

The corrosion behavior of binary zinc-aluminum alloys has often been studied in chloride solutions open to the atmospheric air because of a great influence of the dissolved oxygen on the corrosion kinetics [10-14]. Corrosion rate $v_{\text {corr }}$, which is a quantitative indicator of the general uniform corrosion, can be determined by the weight loss method or by various electrochemical techniques. The weight loss method is time-consuming and a large number of samples is needed to obtain reliable results. However, electrochemical techniques are fast and give an instantaneous rate of a corrosion process, which cannot be obtained by the weight loss method. Corrosion current density $j_{\text {corr }}$, determined by an electrochemical technique, is a quantitative electrochemical indicator of the corrosion rate $[15,16]$. Linear polarization resistance (LPR), electrochemical impedance spectroscopy (EIS) and extrapolation of Tafel lines $[16,17]$ can be applied to obtain the value of corrosion current density of an electrochemical corrosion process. LPR technique and EIS technique are used to obtain the polarization resistance $R_{\mathrm{p}}$ of the electrochemical (corrosion) system [17]. The value of $R_{\mathrm{p}}$ is inversely proportional to the value of corrosion current density $j_{\text {corr }}$ and to the value of corrosion rate $v_{\text {corr }}$. When the value of $R_{\mathrm{p}}$ is known, the corrosion current density $j_{\text {corr }}$ can be calculated using the Stern-Geary equation [18]. The value of $j_{\text {corr }}$ can also be determined from Tafel plots [19]. These plots are obtained by linear sweep voltammetry (LSV) technique.

The main goal of this paper was to apply three electrochemical techniques to test the corrosion resistance of series of $\mathrm{Zn25Al-Si-Sr}$ alloys in the chloride solution. Until now there have been no data on the corrosion behavior of zinc-aluminum alloys modified with silicon and strontium in the corrosive environment containing chlorides, so that results of the tests performed should provide an insight into the possibility of using Zn25AI-Si-Sr alloys in the marine atmosphere.

\section{EXPERIMENTAL PROCEDURE}

\subsection{Materials}

The samples for electrochemical tests were made of Zn25Al-Si-Sr alloys. The designation and chemical composition of these alloys are given in Table 1.

Zn25Al-Si-Sr alloys were prepared by conventional melting and casting route in the Department of Materials Sciences at "Vinča" Institute of Nuclear Sciences. The alloys were melted in the laboratory electric resistance furnace.
Technically pure zinc and aluminum were used in the preparation of these alloys, with the addition of master alloys Al7Si and Al18Si to provide the specified content of silicon. The master alloy Al10Sr was also used, to add the desired strontium content to the alloys. The melted alloys $\left(570{ }^{\circ} \mathrm{C}\right)$ were poured into steel molds preheated to $200^{\circ} \mathrm{C}$. Samples for corrosion tests $(30 \mathrm{~mm} \times 20 \mathrm{~mm} \times 5$ $\mathrm{mm}$ ) were cut from the obtained castings.

Table 1. Chemical composition of Zn25Al-Si-Sr alloys

Tabela 1. Hemijski sastav Zn25Al-Si-Sr legura

\begin{tabular}{|c|c|c|c|c|}
\hline \multirow{2}{*}{ Alloy } & \multicolumn{4}{|c|}{ Chemical element [wt.\%] } \\
\hline & Al & $\mathrm{Si}$ & $\mathrm{Sr}$ & $\mathrm{Zn}$ \\
\hline Zn25Al-1Si & \multirow{3}{*}{25} & \multirow{3}{*}{1.0} & 0.00 & \multirow{3}{*}{ balance } \\
\hline Zn25Al-1Si-0.03Sr & & & 0.03 & \\
\hline Zn25Al-1Si-0.05Sr & & & 0.05 & \\
\hline Zn25Al-3Si & \multirow{3}{*}{25} & \multirow{3}{*}{3.0} & 0.00 & \multirow{3}{*}{ balance } \\
\hline Zn25Al-3Si-0.03Sr & & & 0.03 & \\
\hline Zn25Al-3Si-0.05Sr & & & 0.05 & \\
\hline
\end{tabular}

\subsection{Methods}

The values of corrosion current density of the prepared Zn25Al-Si-Sr alloys are determined by electrochemical techniques. Electrochemical measurements are carried out using a potentiostat/galvanostat BIOLOGIC SP-200 and a three-electrode electrochemical cell for flat samples. A sample with a surface of $1.0 \mathrm{~cm}^{2}$ in contact with the test solution is used as a working electrode. The saturated calomel electrode (SCE) is the reference electrode, and a platinum foil is used as a counter electrode. Electrochemical measurements are performed at room temperature, in a solution of sodium chloride $(3 \mathrm{wt} . \% \mathrm{NaCl}, \mathrm{pH}$ 6.3 ), in the presence of atmospheric oxygen. The test solution simulates the marine atmosphere that contains chloride ions, without the presence of acid gases. Before electrochemical tests the samples were wet ground using progressively finer abrasive SiC paper (600 grit to 1500 grit). Then, they were rinsed with ethanol and dried in the air. The test sample is held in the test solution on the open circuit potential until a stable corrosion potential $E_{\text {corr }}$ is achieved. After that, the sample is electrochemically polarized depending on the applied electrochemical technique.

\section{Linear polarization resistance ( $L P R)$}

This technique is used to obtain the value of polarization resistance $R_{\mathrm{p}}$ of tested electrochemical (corrosion) systems. After reaching stable corrosion potential $E_{\text {corr }}$, the working electrode (test sample) is electrochemically polarized in a small range of potential $( \pm 10 \mathrm{mV})$ near $E_{\text {corr }}$ and the corresponding polarization curve is recorded. The applied sweep rate is $1 \mathrm{mV} / \mathrm{s}$. The value of $R_{\mathrm{p}}$ is 
determined as the slope of the experimental $E-j$ curve on the $E_{\text {corr }}$.

\section{Electrochemical Impedance Spectroscopy (EIS)}

The values of $R_{\mathrm{p}}$ for all $\mathrm{Zn} 25 \mathrm{Al}-\mathrm{Si}-\mathrm{Sr}$ alloys are also determined by electrochemical impedance spectroscopy. This technique is usually performed by applying an AC potential to an electrochemical (corrosion) system and then measuring the corresponding AC current. The AC signal is applied over a wide range of frequencies $(0.01 \mathrm{~Hz}$ to 100 $\mathrm{kHz}$ ) to generate an impedance spectrum for the tested corrosion system. The value of $R_{p}$ is determined from the so-called Nyquist plot, by reading the real axis value of the electrochemical impedance $Z$ at high and low frequencies.

Three LPR tests and three EIS tests are performed for each test sample (Zn25Al-Si-Sr alloys), with good reproducibility. The value of corrosion current density $j_{\text {corr }}$ is calculated using the experimental $R_{\mathrm{p}}$ value for each test sample.

Linear sweep voltammetry (LSV)

After LPR test and EIS test, the test sample is subjected to potentiodynamic polarization using a linear sweep voltammetry technique (LSV). The
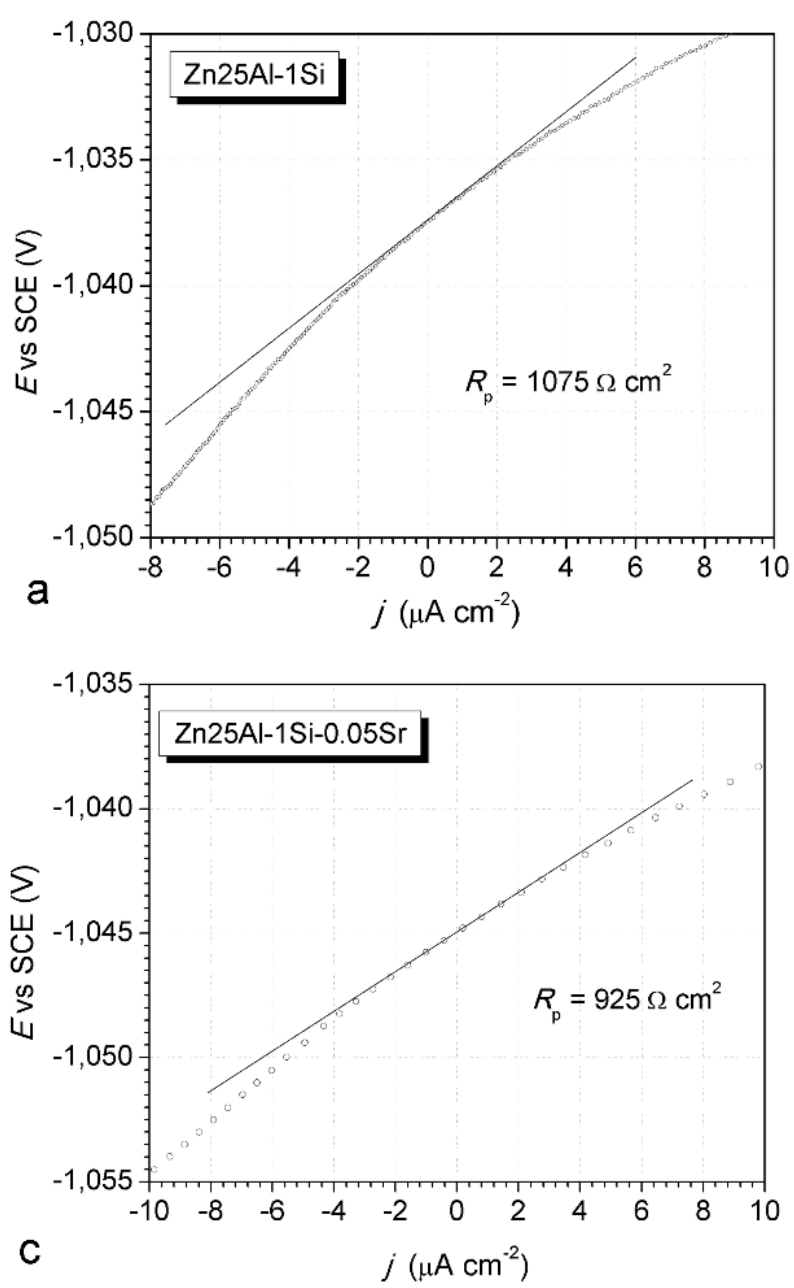

sample is polarized in a wide potential range $( \pm$ $0.150 \mathrm{~V}$ vs $E_{\text {corr }}$ ) at a sweep rate of $1 \mathrm{mV} / \mathrm{s}$, and the corresponding polarization curve was recorded. The value of corrosion current density $j_{\text {corr }}$ is determined directly from the obtained $E-\log j$ plot (Tafel plot), by extrapolation of the linear part of the anodic polarization curve to the corrosion potential $E_{\text {corr. }}$.

\section{RESULTS AND DISCUSSION}

\subsection{E-j graphs}

Experimental $E-j$ graphs for Zn25Al-Si-Sr alloys are obtained by linear polarization resistance technique. The graphs are shown in Figure 1.

The current density $j$ on the corrosion potential $E_{\text {corr }}$ is $j=0$. The negative current densities correspond to the cathodic current densities, while the positive current densities correspond to the anodic current densities. The slope $(\Delta E / \Delta /)$ on the corrosion potential $E_{\text {corr }}$ is the polarization resistance $R_{\mathrm{p}}$. The value of $R_{\mathrm{p}}$, which is obtained from experimental $E-j$ graphs for each Zn25Al-SiSr alloy (Figure $1 \mathrm{a}-\mathrm{f}$ ), is given in Table 2 .
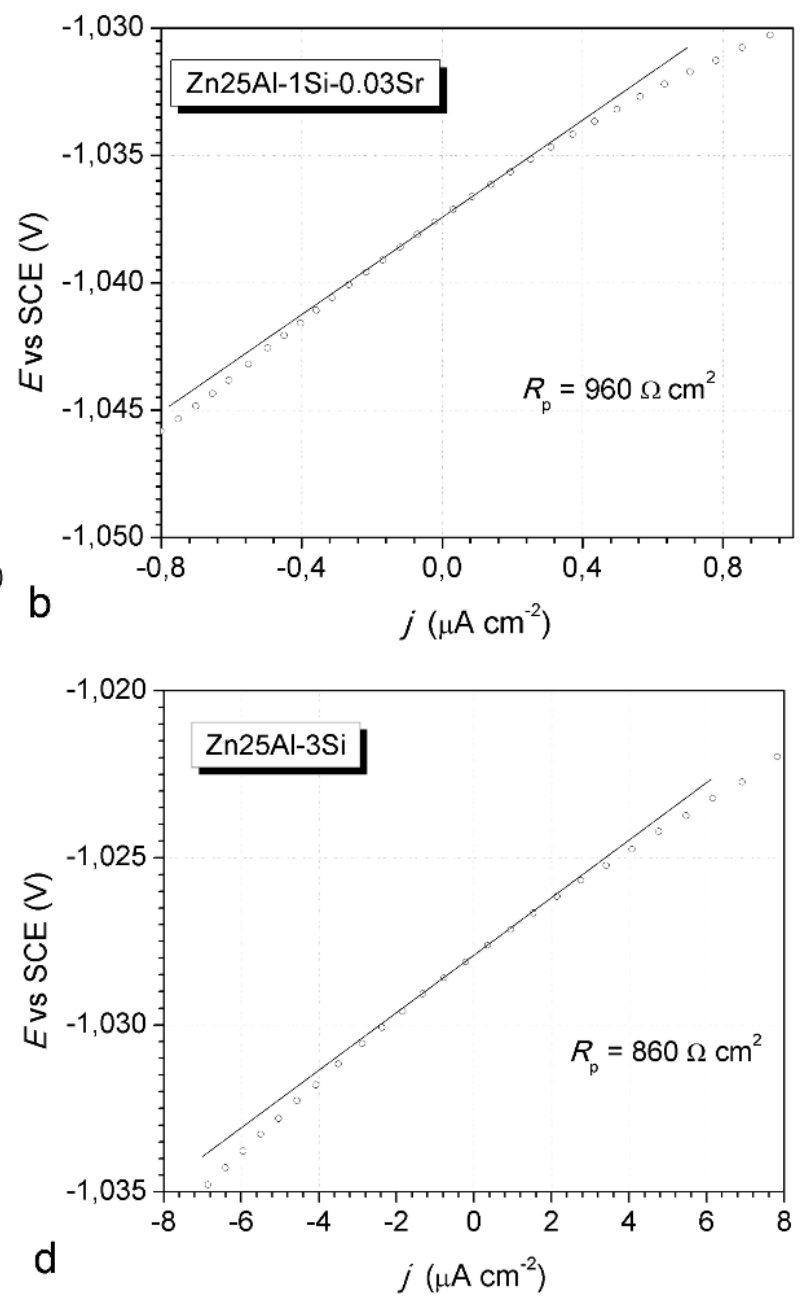

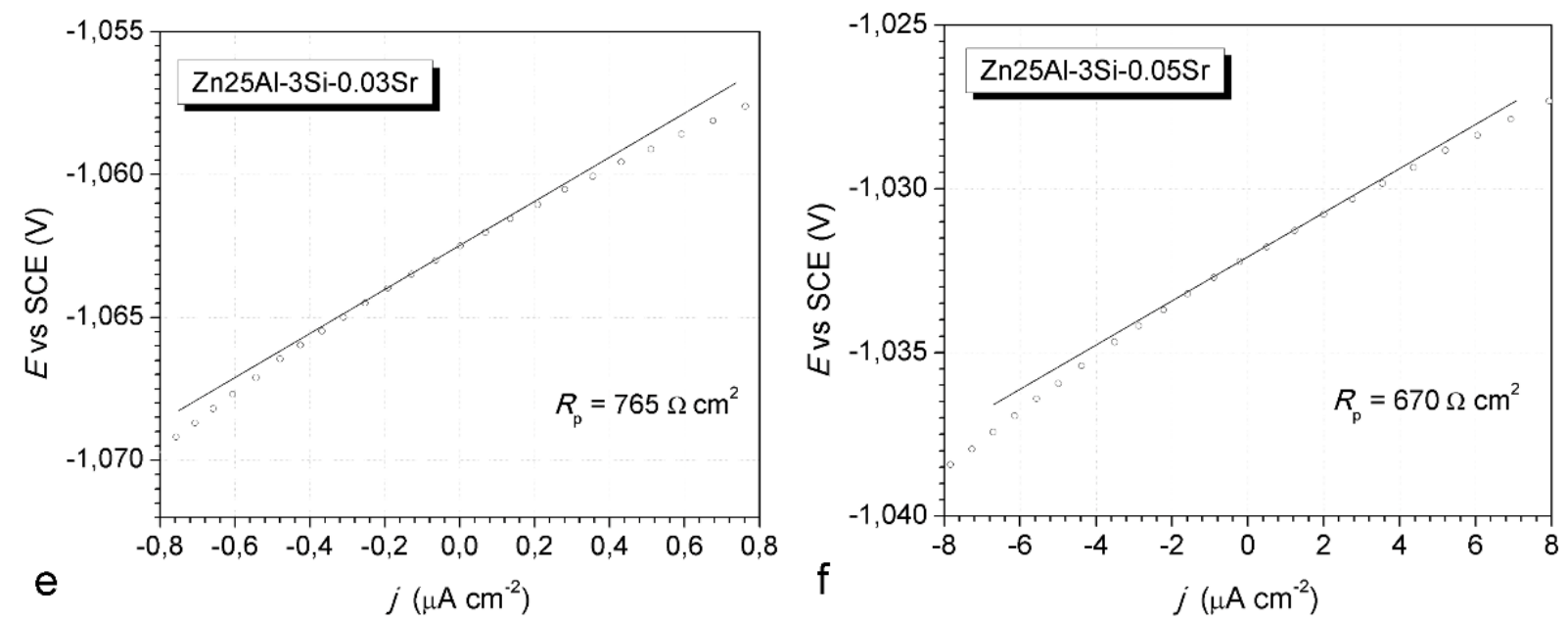

Figure 1. E-j graphs for Zn25Al-Si-Sr alloys in sodium chloride solution (3 wt.\% $\mathrm{NaCl}$ ).

Slika 1. E-j dijagrami za Zn25Al-Si-Sr legure u rastvoru natrijum hlorida (3 wt.\% $\mathrm{NaCl}$ ).

\subsection{Nyquist plots}

Experimental data obtained using Electrochemical Impedance Spectroscopy are shown in Figure 2 a-f. The data are presented in the form of

Nyquist plots. A Nyquist plot shows the dependence of the real impedance component $\left(Z_{\mathrm{Re}}\right)$ and the imaginary impedance component $\left(Z_{\text {im }}\right)$ on frequency $f$, in linear coordinates.

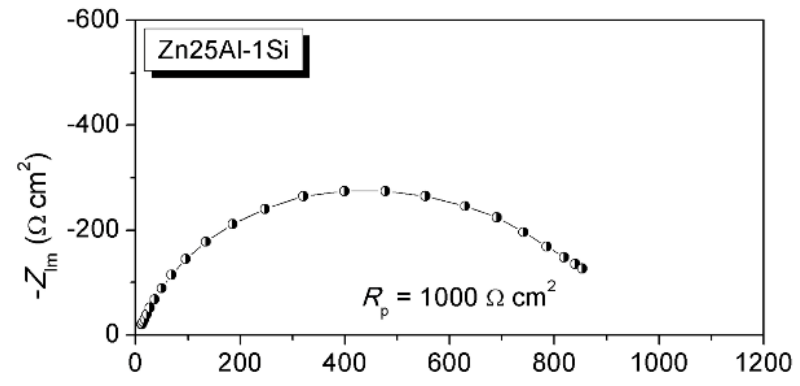

a $Z_{\mathrm{Re}}\left(\Omega \mathrm{cm}^{2}\right)$

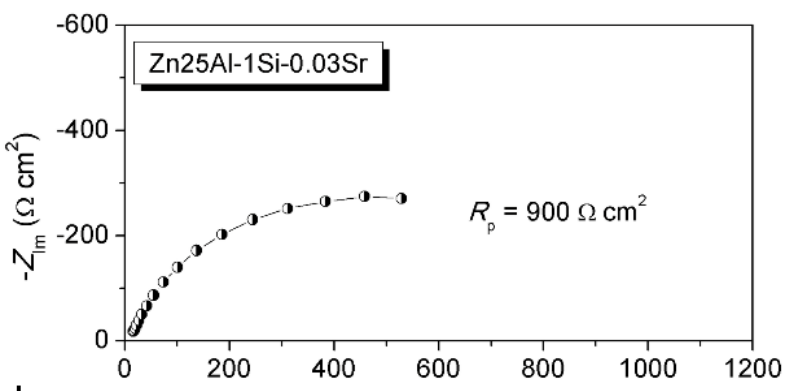

b $Z_{\mathrm{Re}}\left(\Omega \mathrm{cm}^{2}\right)$

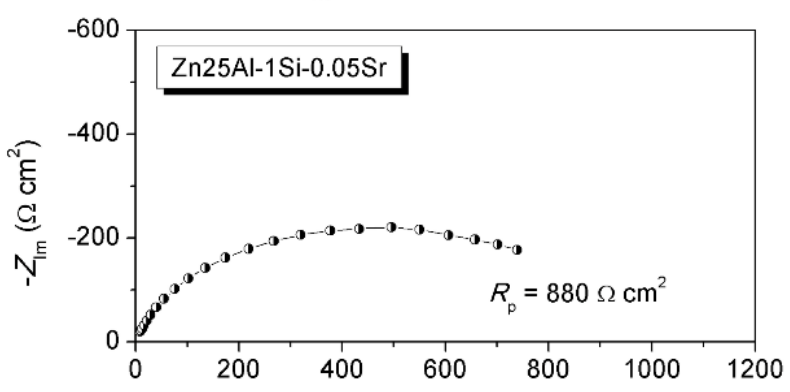

C $Z_{\mathrm{Re}}\left(\Omega \mathrm{cm}^{2}\right)$
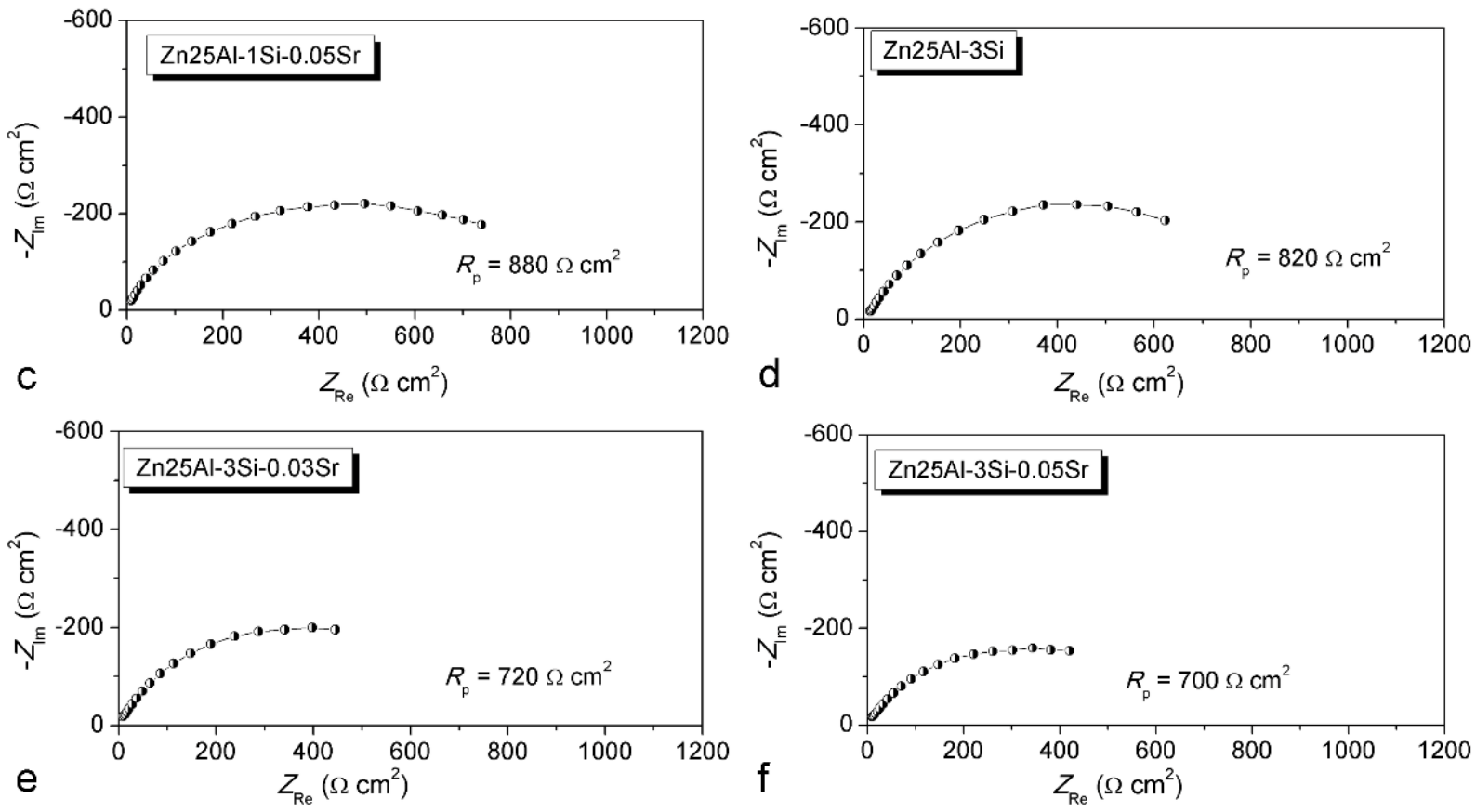

Figure 2. Nyquist plots for Zn25Al-Si-Sr alloys in sodium chloride solution (3 wt.\% NaCl).

Slika 2. Nyquist dijagrami za Zn25Al-Si-Sr legure u rastvoru natrijum hlorida (3 wt.\% NaCl). 
Resistance of test solution can be obtained by reading the real axis value at the high frequency intercept (left side of the plot). The real axis value at the low frequency intercept (right side of the plot) is the sum of the polarization resistance $R_{\mathrm{p}}$ and the resistance of test solution. Therefore, the diameter of the semicircle in the Nyquist plot is equal to the value of polarization resistance $R_{\mathrm{p}}$. The values of $R_{\mathrm{p}}$ determined by EIS technique for all Zn25AI-SiSr alloys are shown in Figure 2 a-f and they are also given in Table 2 .

When the value of polarization resistance $R_{\mathrm{p}}$ is known, the value of corrosion current density $j_{\text {corr }}$ can be calculated using the Stern-Geary equation [18]:

$$
j_{\text {corr }}=\frac{B}{R_{p}}
$$

$B$ is a constant that depends on the values of the anodic and cathodic Tafel slope $b_{\mathrm{a}}$ and $b_{\mathrm{c}}$ :

$$
B=\frac{b_{a} \times b_{c}}{2.3 \times\left(b_{a+} b_{c}\right)}
$$

Equation (2) applies when both cathodic and anodic reactions are activation controlled. If the anodic reaction is under the charge-transfer control while the cathodic reaction is controlled by diffusion, the modified Stern-Geary equation is used [15]:

$$
j_{\text {corr }}=\frac{b_{a}}{2.3 \times R_{p}}
$$

Corrosion of each Zn25Al-Si-Sr alloy in the test solution takes place through anodic dissolution of the alloy. The anodic reaction is under the chargetransfer control with anodic Tafel slope $b_{a}=30$ $\mathrm{mV} /$ decade (Figure 3 ). The cathodic reaction is controlled by diffusion of oxygen in the test solution $[15,17]$. In that case, the value of cathodic Tafel slope $b_{c} \rightarrow \infty$ and Equation (3) should be used to calculate the value of corrosion current density $j_{\text {corr }}$.

$R_{\mathrm{p}}$ values are experimental values, obtained when using LPR and EIS techniques. Calculated values of the corrosion current density for tested Zn25Al-Si-Sr alloys are given in Table 2.

\subsection{E-log j graphs (Tafel plots)}

Potentiodynamic polarization curves for the tested zinc-aluminum alloys with silicon and strontium are obtained by LSV technique. Experimental anodic and cathodic polarization curves for each Zn25Al-Si-Sr alloy are shown in Figure 3.

The anodic polarization curves in Figure 3 a-f show an increase in the current density when the applied polarization increases, indicating the anodic dissolution of Zn25Al-Si-Sr alloys. The curves are linear in the marked current region and the value of anodic Tafel slope $b_{\mathrm{a}} \sim 30 \mathrm{mV} /$ decade for all Zn25Al-Si-Sr alloys. On the other hand, in the cathodic region, the current density plateau is clearly visible. This behavior is a characteristic of the process controlled exclusively by diffusion. In neutral solutions open to the atmosphere, dissolved oxygen is the main cathodic reactant [16]. The transport of oxygen to the electrode surface (test sample) is limited due to a low solubility of oxygen in the test solution. The cathodic reaction (the reduction of oxygen) is controlled by diffusion and the value of cathodic Tafel slope $b_{\mathrm{c}} \rightarrow \infty$.

The value of corrosion current density $j_{\text {corr }}$ for each Zn25Al-Si-Sr alloy is obtained directly from the characteristic Tafel plot (Figure 3 a-f), by extrapolating the linear part of the anodic polarization curve to the corresponding $E_{\text {corr }}$ value. The experimental values of $j_{\text {corr }}$ for the tested Zn25Al-Si-Sr alloys are given in Table 2. Table 2 summarizes all quantitative results of the performed electrochemical tests.

Table 2. Indicators of resistance to general corrosion for Zn25Al-Si-Sr alloys, obtained by various electrochemical techniques

Tabela 2. Pokazatelji otpornosti na opštu koroziju Zn25Al-Si-Sr legura, dobijeni različitim elektrohemijskim tehnikama

\begin{tabular}{|c|c|c|c|c|c|}
\hline \multirow{2}{*}{ Alloy } & \multicolumn{2}{|c|}{ LPR technique } & \multicolumn{2}{c|}{ EIS technique } & LSV technique \\
\cline { 2 - 6 } & $\begin{array}{c}R_{\mathrm{p}} \\
{\left[\Omega \mathrm{cm}^{2}\right]}\end{array}$ & $\begin{array}{c}j_{\text {corr }} \\
{\left[\mu \mathrm{cm}^{-1}\right]}\end{array}$ & $\begin{array}{c}R_{\mathrm{p}} \\
{\left[\Omega \mathrm{cm}^{2}\right]}\end{array}$ & $\begin{array}{c}j_{\text {corr }} \\
{\left[\mu \mathrm{A} \mathrm{cm}{ }^{-1}\right]}\end{array}$ & $\begin{array}{c}j_{\text {corr }} \\
{\left[\mu \mathrm{A} \mathrm{cm}{ }^{-1}\right]}\end{array}$ \\
\hline ZA27 & 1250 & 10.4 & 1220 & 10.7 & 8 \\
\hline Zn25Al-1Si & 1075 & 12.1 & 1000 & 13.0 & 10 \\
\hline Zn25Al-1Si-0.03Sr & 960 & 13.6 & 920 & 14.2 & 13 \\
\hline Zn25Al-1Si-0.05Sr & 925 & 14.1 & 880 & 14.8 & 14 \\
\hline Zn25Al-3Si & 860 & 15.2 & 820 & 15.9 & 15 \\
\hline Zn25Al-3Si-0.03Sr & 765 & 17.0 & 720 & 18.1 & 17 \\
\hline Zn25Al-3Si-0.05Sr & 670 & 19.4 & 700 & 18.6 & 20 \\
\hline
\end{tabular}




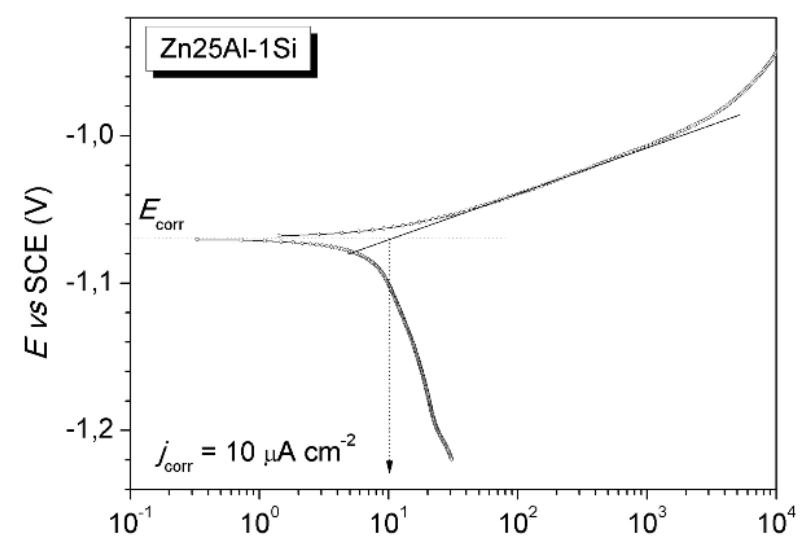

a

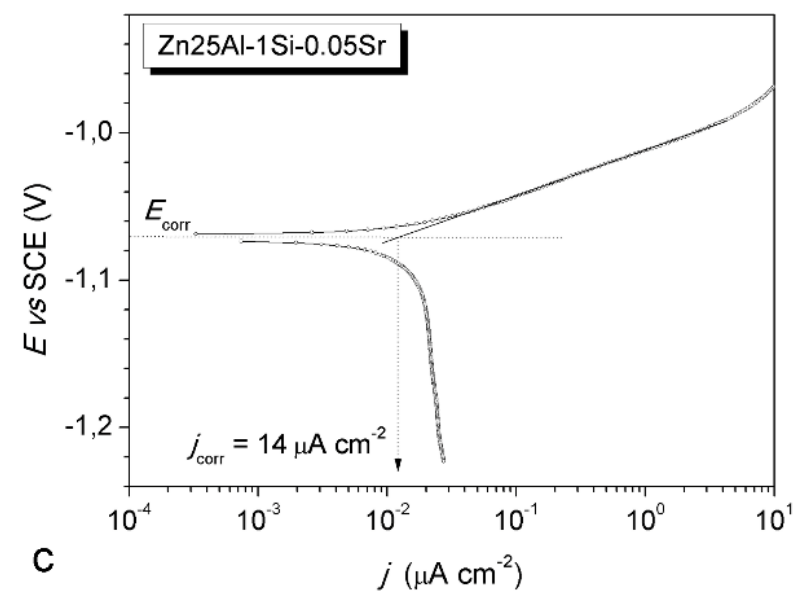

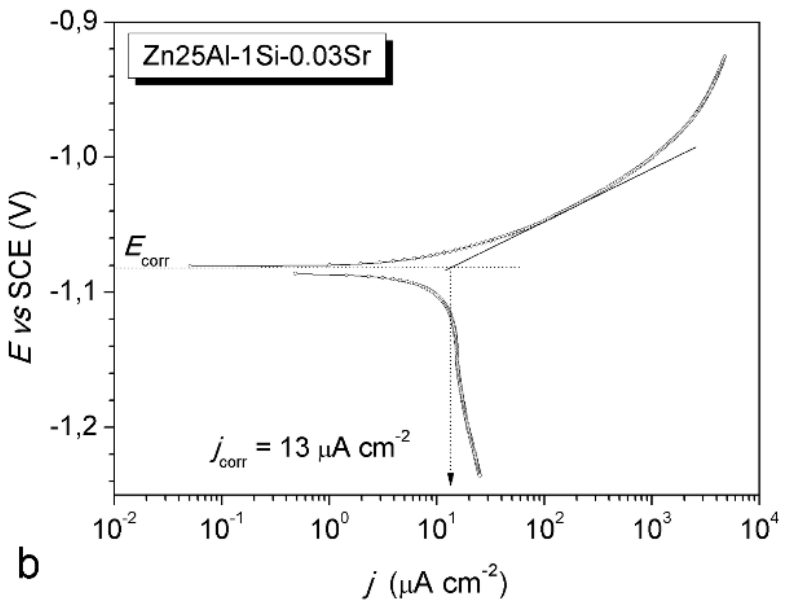
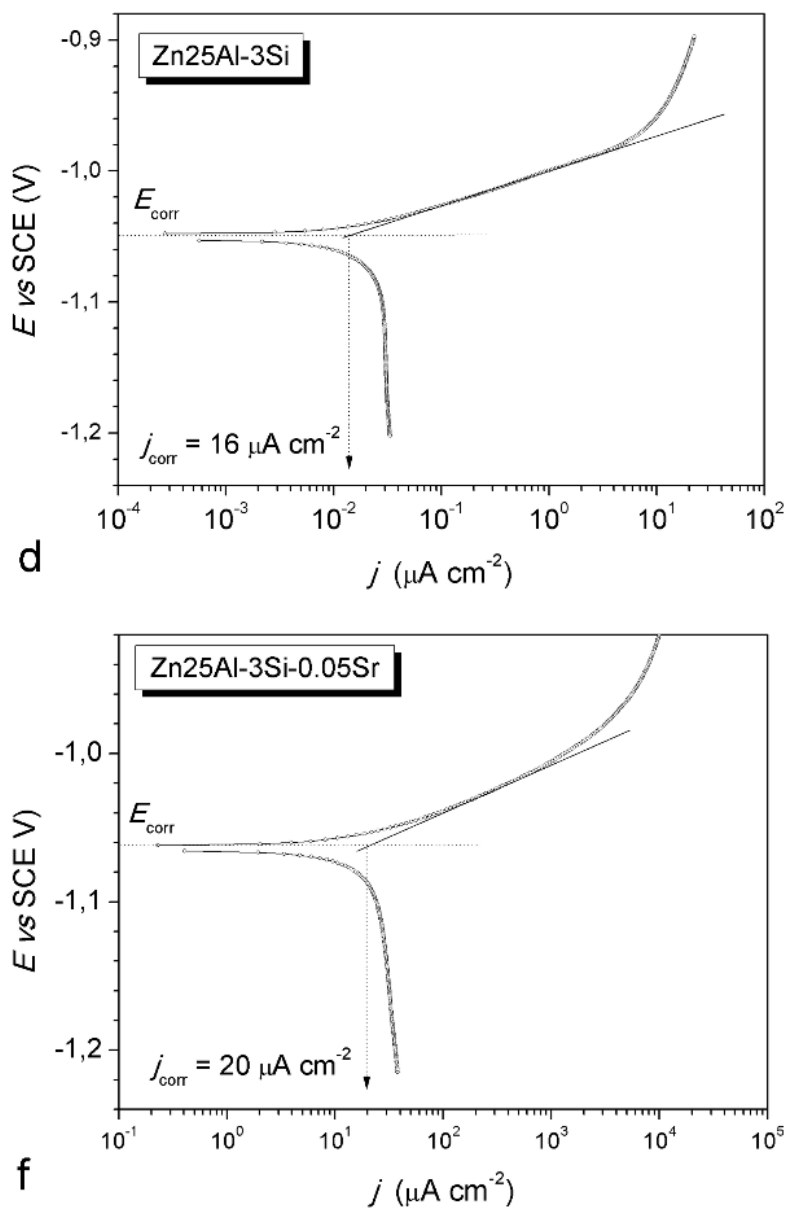

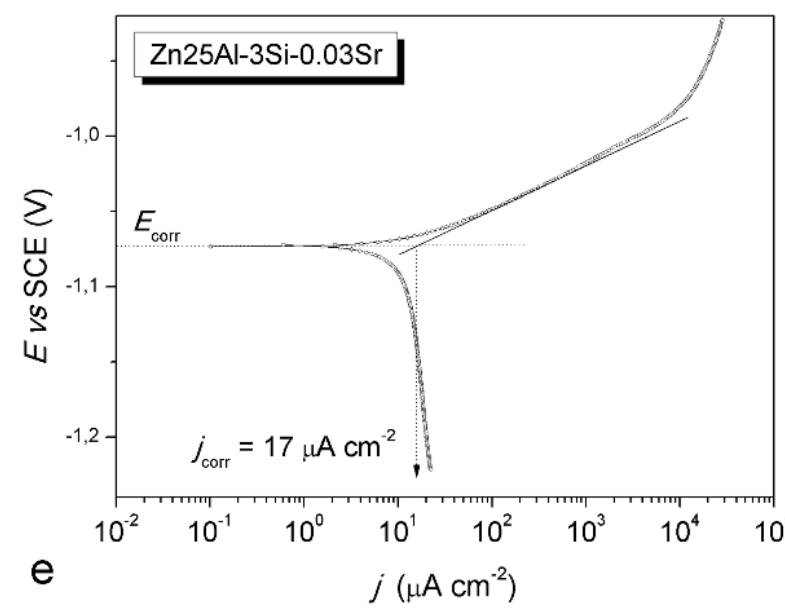

Figure 3. E-log j graphs (Tafel plots) for Zn25Al-Si-Sr alloys in sodium chloride solution (3 wt.\% NaCl).

Slika 3. E-log j dijagrami (Tafelovi dijagrami) za Zn25Al-Si-Sr legure u rastvoru natrijum hlorida (3 wt.\% NaCl).

The values of $R_{\mathrm{p}}$ and $j_{\text {corr }}$ for the commercial ZA27 alloy are also given in Table 2, for the purpose of comparison. The alloy was supplied from the $\operatorname{RAR}^{{ }^{\circledR}}$ foundry, Batajnica. The same electrochemical techniques were used to determine the values of $R_{\mathrm{p}}$ and $j_{\text {corr }}$, as in the case of $\mathrm{Zn} 25 \mathrm{Al}$ $\mathrm{Si}-\mathrm{Sr}$ alloys. The obtained results are given in Figure 4.
Table 2 shows that the highest value of polarization resistance $R_{\mathrm{p}}$ and the lowest value of corrosion current density $j_{\text {corr }}$ are obtained in the case of commercial ZA27 alloy. A slightly higher value of $j_{\text {corr }}$ is obtained for $Z$ n25Al-1Si alloy without strontium. When the content of silicon and strontium increases in $\mathrm{Zn} 25 \mathrm{Al}-\mathrm{Si}-\mathrm{Sr}$ alloys, the value of $R_{\mathrm{p}}$ slightly decreases, which leads to a small increase in the value of $j_{\text {corr }}$. Among all 
Zn25Al-Si-Sr alloys, the alloy with the largest content of silicon and strontium i.e. Zn25Al-3Si$0.05 \mathrm{Sr}$ alloy, has the lowest value of polarization resistance $R_{\mathrm{p}}$ and the highest value of corrosion

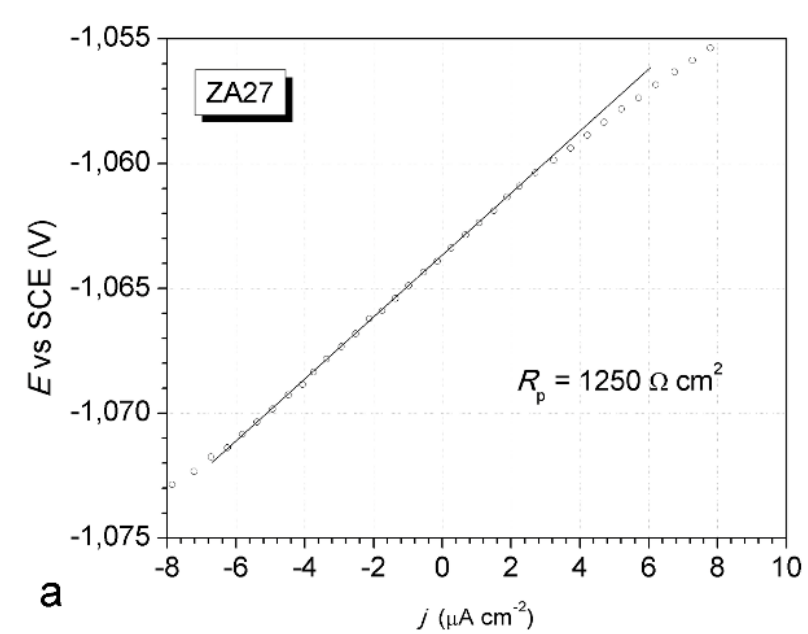

current density $j_{\text {corr }}$. Accordingly, the presence of silicon and strontium in Zn25Al-Si-Sr alloys resulted in a lower resistance to corrosion of these alloys compared to the commercial ZA27 alloy.

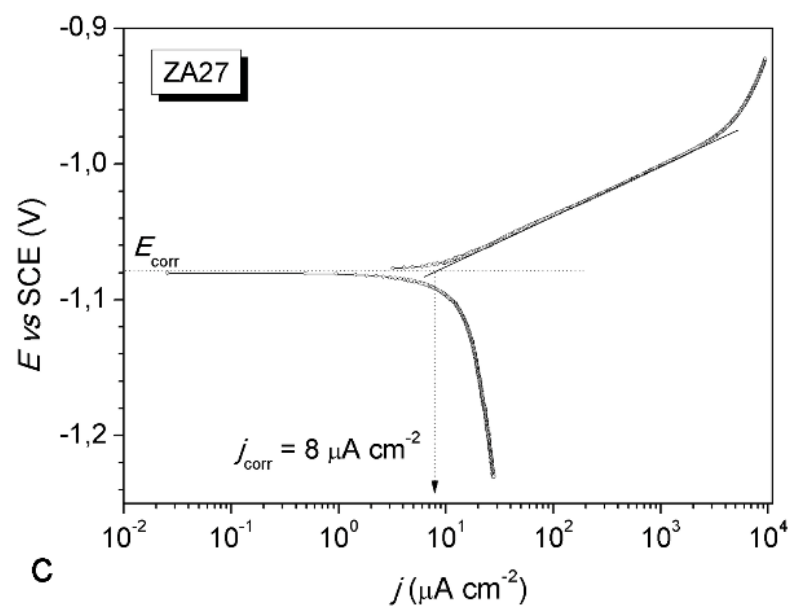

Figure 4. Results of electrochemical tests for commercial ZA27 alloy in sodium chloride solution (3 wt.\% NaCl): a) E-j graph, b) Nyquist plot and c) E-log j graph (Tafel graph).

Slika 4. Rezultati elektrohemijskih ispitivanja komercijalne ZA27 legure u rastvoru natrijum hlorida (3 wt.\% NaCl): a) E-j dijagram, b) Nyquist dijagram i c) E-log j dijagram (Tafelov dijagram).

The values of $R_{\mathrm{p}}$ obtained by LPR and EIS technique are very close. It can also be seen that the values of $j_{\text {corr }}$ for all $\mathrm{Zn} 25 \mathrm{Al}-\mathrm{Si}-\mathrm{Sr}$ alloys, determined by different electrochemical techniques, are in very good agreement.

\section{CONCLUSIONS}

The resistance to general corrosion of the series of zinc-aluminum alloys with silicon and strontium (Zn25Al-Si-Sr alloys) was tested in sodium chloride solution, using various electrochemical techniques. The process of corrosion occurs as anodic dissolution of the alloys. The anodic reaction is under the charge-transfer control while the cathodic reaction is controlled by diffusion of oxygen in the test solution. With the increase in silicon and strontium content in the synthesized Zn25Al-Si-Sr alloys, the value of the corrosion current density $j_{\text {corr }}$ increases gradually.

This indicates a lower resistance to general corrosion of $\mathrm{Zn} 25 \mathrm{Al}-\mathrm{Si}-\mathrm{Sr}$ alloys, compared to the corrosion resistance of the commercial ZA27 alloy. However, the difference in the level of general corrosion is small, which can be significant for further development and wider application of zincaluminum alloys with silicon and strontium. The relatively low values of corrosion current density $j_{\text {corr }}$, obtained for Zn25Al-Si-Sr alloys in the sodium chloride solution, point to the potential use of these alloys in various tribo-mechanical systems designed to work in the marine atmosphere. 


\section{Acknowledgement}

The authors are grateful to the Ministry of Education, Science and Technological Development of the Republic of Serbia for the financial support of this work through Projects OI 172005 and TR 35021.

\section{REFERENCES}

[1] E.Gervais, R.J.Barnhurst, C.A.Loong (1985) An analysis of selected properties of ZA alloys, Journal of Metals (JOM), 37(11), 43-47.

[2] T.Savaskan, S.Murphy (1987) Mechanical properties and lubricated wear of $\mathrm{Zn}-25 \mathrm{Al}$ based alloys, Wear, 116(2), 211-224.

[3] S.Murphy, T.Savaskan (1987) Metallography of zinc-25\% Al based alloys in the as-cast and aged conditions, Practical Metallography, 24(5), 204-221.

[4] A.Zyska, Z.Konopka, M.Ła,giewka, M.Nadolsk (2011) Structure and selected properties of highaluminium $\mathrm{Zn}$ alloy with silicon addition, Archives of Foundry Engineering 11(13), 261-264.

[5] F.Mao, F.Chen, G.Yan, T.Wang, Z.Cao (2015) Effect of strontium addition on silicon phase and mechanical properties of Zn-27Al-3Si alloy, Journal of Alloys and Compounds, 622, 871-879.

[6] L.Jian, E.E.Laufer, J.Masounave (1993) Wear in Zn-Al-Si alloys, Wear, 165(1), 51-56.

[7] A.Vencl, I.Bobić, F.Vučetić, B.Bobić, J. Ružić (2014) Structural, mechanical and tribological characterization of $\mathrm{Zn} 25 \mathrm{Al}$ alloys with $\mathrm{Si}$ and $\mathrm{Sr}$ addition, Materials and Design, 64, 381-392.

[8] X.G. Zhang (1996) Corrosion and Electrochemistry of Zinc, Springer Science+Bussiness Media, New York.

[9] F.C. Porter (1994) Corrosion Resistance of Zinc and Zinc Alloys, Marcell Dekker, New York.
[10] A.E.Ares, L.M.Gassa (2012) Corrosion susceptibility of $\mathrm{Zn}-\mathrm{Al}$ alloys with different grains and dendritic microstructures in $\mathrm{NaCl}$ solutions, Corrosion Science, 59, 290-306.

[11] L.Yang, Y.Zhang, X.Zeng, Z.Song (2012) Corrosion behaviour of superplastic $\mathrm{Zn}-\mathrm{Al}$ alloys in simulated acid rain, Corrosion Science, 59, 229-237.

[12] W.R.Osorio, C.M.Freire, A.Garcia (2005) The effect of the dendritic microstructure on the corrosion resistance of $\mathrm{Zn}-\mathrm{Al}$ alloys, Journal of Alloys and Compounds, 397, 179-191.

[13] A.E.Ares, L.M.Gassa, C.E.Schvezov, M.R. Rosenberger (2012) Corrosion and wear resistance of hypoeutectic $\mathrm{ZnAl}$ alloys as a function of structural features, Materials Chemistry and Physics, 136, 394-414.

[14] B. Bobic, J. Bajat, Z. Acimovic-Pavlovic, M. Rakin, I. Bobic (2011) The effect of T4 heat treatment on the microstructure and corrosion behavior of Zn27Al1.5Cu0.02Mg alloy, Corrosion Science, 53, 409-417.

[15] L.L.Shreir, R.A.Jarman, G.T.Burstein Corrosion, Butterworth-Heinemann, Oxford.

[16] P.Marcus, F.Mansfeld (2006) Analytical Methods in Corrosion Science and Engineering, CRC Press Taylor \& Francis Group, Boca Raton.

[17] R.G.Kelly, J.R.Scully, D.W.Shoesmith, R.G. Buchheit (2002) Electrochemical Techniques in Corrosion Science and Engineering, Marcell Dekker, New York.

[18] M.Stern, A.L.Geary (1957) A Theoretical Analysis of the Shape of Polarization Curves, Journal of Electrochemical Society, 104, 56-63.

[19] N.Perez (2004) Electrochemistry and Corrosion Science, Kluwer Academic Press, New York.

\title{
IZVOD \\ OTPORNOST NA OPŠTU KOROZIJU SERIJE LEGURA CINK-ALUMINIJUM KOJE SU MODIFIKOVANE SILICIJUMOM I STRONCIJUMOM
}

\begin{abstract}
Otpornost na koroziju serije legura cink-aluminijum za livenje, koje su modifikovane silicijumom i stroncijumom, ispitana je u rastvoru natrijum hlorida. Pokazano je da je opšta korozija glavni oblik korozije Zn25Al-Si-Sr legura u navedenom rastvoru. Proces korozije odvija se kao anodno rastvaranje legura, dok je katodna reakcija kontrolisana difuzijom kiseonika u rastvoru. Tri različite elektrohemijske tehnike primenjene su za određivanje gustine struje korozije, koja je elektrohemijski pokazatelj brzine korozije. Vrednost gustine struje korozije za svaku Zn25Al-Si-Sr leguru izračunata je na osnovu vrednosti polarizacione otpornosti, koja je određenai spektroskopijom elektrohemijske impedanse ili tehnikom linearne polarizacije. Vrednost gustine struje korozije je takođe određena direktno iz Tafelovih dijagrama, koji su registrovani pomoću voltametrije sa linearnom promenom potencijala. Sa povećanjem sadržaja silicijuma $i$ stroncijuma $u$ ispitivanim legurama vrednost gustine struje korozije postepeno raste. Rezultati dobijeni različitim elektrohemijskim tehnikama su u dobroj saglasnosti.
\end{abstract}

Ključne reči: legure cink-aluminijum, korozija, brzina korozije, elektrohemijske tehnike.

Naučni rad

Rad primljen: 04.07.2018.

Rad korigovan: 22.08.2018.

Rad prihvaćen: 25.08.2018.

Rad je dostupan na sajtu: www.idk.org.rs/casopis

(c) 2019 Authors. Published by Engineering Society for Corrosion. This article is an open access article distributed under the terms and conditions of the Creative Commons Attribution 4.0 International license (https://creativecommons.org/licenses/by/4.0/) 